\title{
From Kyai to Politicians: The Intellectual-Political Journey of K.H. Abdurrahman Chudlori 1943-2011
}

\author{
Khoirul Murti Ulfiyah \\ IAIN Salatiga \\ khoirulmurti@gmail.com
}

\begin{abstract}
K.H Abdurrahman Chudlori is the caretaker of the Tegalrejo Islamic Boarding School Boarding School, Magelang. K.H Abdurrahman Chudlori became one of the influential figures in Magelang, especially in Tegalrejo. K.H Abdurrahman Chudlori also played an active role in society. In addition, K.H Abdurrahman Chudlori is also active in political parties, even being one of the founders of the PKNU Party. In this research, the author uses historical research methods that include collecting sources in written and oral, source criticism, interpretation or interpretation, and writing history or historiography. The results of this study are; (1) K.H. Abdurrahman Chudlori is a persistent learning person, a figure who becomes a role model for the community because he cares for the community very high, always prioritizes the welfare of the community (2) K.H. Abdurrahman Chudlori is the caretaker of the large Islamic Boarding School Magelang Islamic Education Dormitory, Kyai who has a charismatic figure, (3) K.H. Abdurrahman Chudlori is active in the NU Ormas, he is also active in three political parties and is one of the founders of the PKNU Party.
\end{abstract}

Keywords: K.H Abdurrabman Chudlori; Kyai; Politics

\begin{abstract}
Abstrak
K.H Abdurrahman Chudlori merupakan pengasuh Pondok Pesantren Asrama Perguruan Islam Tegalrejo, Magelang. K.H Abdurrahman Chudlori menjadi salah satu tokoh yang berpengaruh di Magelang khususnya di Tegalrejo, K.H Abdurrahman Chudlori juga sangat berperan aktif dalam masyarakat. Selain itu, K.H Abdurrahman Chudlori juga aktif dalam partai politik, bahkan menjadi salah satu pendiri Partai PKNU. Dalam penelitian ini, penulis menggunakan metode penelitian sejarah yang meliputi; pengumpulan sumber berupa tertulis dan lisan, kritik sumber, penafsiran atau interpretasi, dan penulisan sejarah atau historiografi. Adapun hasil dari penelitian ini, adalah; (1) K.H Abdurrahman Chudlori
\end{abstract}


JNUS: Journal of Nahdlatul Ulama Studies, Vol. 2, No. 1, Januari 2021: 47-66

seorang yang gigih dalam belajar, sosok yang menjadi panutan masyarakat karna keperdulian beliau di masyarakat sangat tinggi, selalu mementingkan kesejahteraan masyarakat (2) K.H Abdurrahman Chudlori merupakan pengasuh Pondok Pesantren besar Asrama Pendidikan Islam Magelang, Kyai yang mempunyai figur kharismatis, (3) K.H Abdurrahman Chudlori aktif dalam Ormas NU, beliau juga aktif dalam tiga Partai Politik dan menjadi salah satu pendiri Partai PKNU.

Kata Kunci: K.H Abdurrahman Chudlori; Kyai; Politik

\section{INTRODUCTION}

Islamic boarding schools are one of the means of Islamic education in Indonesia, especially in the Central Java area. One of the most famous Islamic boarding schools in the Islamic Education Boarding School (API) is Tegalrejo, Magelang, Central Java. This pesantren was founded by a scholar named K.H. Chudlori on September 15th,1947. K.H Chudlori has two wives. The first wife has two sons and two daughters; from the second wife, he has four sons and two daughters. After K.H. Chudlori died in 1977, he handed over the care of the boarding school to the eldest son of his first wife, K.H Abdurrahman Chudlori. (Interview in November 2017 at PP API).

As a scholar, Abdurrahman Chudlori, more often called Mbah Dur, always had different thoughts from other kyai-kyai. One of his most prominent thoughts is in education, which is to form an institution that focuses on religious education and education with a social dimension that can be useful and useful for students and the surrounding community. Thus, the Syubbanul Wathon Foundation is engaged in animal farming and agriculture, managed by Mbah Dur's younger brother, K.H. M Yusuf Chudlori. Over time, this foundation developed into formal education, including Integrated Islamic Kindergarten, Ma'arif Integrated Islamic Elementary School, S.M.P., S.M.K., and Syubbanul Wathon Islamic High School (interview on December 8th, 2017 at PP API).

Apart from being the caretaker of the API Islamic boarding school, Mbah Dur is also active in politics, starting from PPP, PKB, and PKNU. His politics began when his father asked him to participate in the PPP campaign in the 1977 elections. 


\section{RESEARCH METHODS}

As Louis Gottschalk (1975: 32) mentioned, the research method that will be used is that the essence of the historical method meets four main activities: 1). collection of relevant written and oral sources called heuristics; 2). get rid of materials that are not authentic or called criticism; 3). conclude credible testimony or interpretation, and 4). the compilation of testimony into a story or meaningful presentation is known as the historiography stage.

\section{RESULTS AND DISCUSSIONS}

\section{Childhood and Educational History of K.H. Abdurrahman Chudlori} Family's Background

K.H. Abdurrahman Chudlori was born on December 31, 1943. He was born to K.H. Chudlori and her mother named Khunah (Interview on December $8^{\text {th }}, 2017$ at PP API). Nyai Khunah is the daughter of K.H Dalhar (K.H Nahrowi) caretaker of the Darussalam Watucongol Islamic Boarding School, Muntilan, Magelang. After married, K.H, Chudlori was asked to teach at Pondok Watucongol. After being blessed with a child who was none other than K.H Abdurrahman Chudlori, K.H Chudlori and their family moved to Tegalrejo, Magelang, and founded the Islamic Education Dormitory Boarding School (API). K.H Chudlori is a child born to a prince in Tegalrejo, K.H Chudlori, the second of ten children. However, K.H Chudlori's father was born a priyayi family. Still, K.H Chudlori's father wanted one of his children to become a kyai.

K.H. Abdurrahman Chudlori was born into a religious family. His father was a great scholar and a pioneer in the Islamic Education Boarding School (API) in Tegalrejo, Magelang, Central Java. During his childhood, K.H Abdurrahman Chudlori had studied the Koran. The life of a boarding school was no longer strange to him. In 1950, he studied the Koran and studied religion under his father, K.H. Chudlori. K.H Abdurrahman at the Islamic Education Dormitory Boarding School built by his father (Interview on October 30 32018 at PP Al-Riyadloh Tuntang).

K.H Abdurrohman is the first of three children. His second brother was named K.H Achmad Muhammad, and his third brother was named Hj. Wisah Aisyah (Interview on 08 December 2017 at PP API). 
JNUS: Journal of Nahdlatul Ulama Studies, Vol. 2, No. 1, Januari 2021: 47-66

After K.H Abdurrahman Chudlori's mother died in 1951, her father, K.H Chudlori, remarried in 1952 to a Nur Halimah.

Even though Kyai Abdurrahman grew up in a boarding school environment, it does not mean that he has put aside formal education during his childhood. It's just that religious education has a larger and wider portion. Kyai Abdurrahman Chudlori is expected and directed as the next generation responsible for continuing the Islamic Boarding School, which his father pioneered. (Nurul Islam, 2007: 58)

\section{K.H Abdurrahman Chudlori Household}

K.H Abdurrahman Chudlori was married twice during his first lifetime to $\mathrm{Hj}$. Muthmainah and the second with $\mathrm{Hj}$. Faizah. From his first marriage to $\mathrm{Hj}$. Mutmainah was blessed with four children, namely, K.H Nasrul Arif (Gus Nas), K.H Akhmad Izzuddin, Lc., M.S.I. (Gus Din), Kuni Sa'adati, and Nur Kholida (Nurul Islam, 2007: 55). The first child, K.H Nasrul Arif, is still trusted to be the caretaker of the Syubbanul Wathon Islamic Boarding School. The second child, K.H Akhmad Izzuddin, Lc., M.S.I., is believed to continue the school, which is also a foundation with the Syubabanul Wathon Islamic Boarding School. Meanwhile, his second marriage with $\mathrm{Hj}$. Faizah is blessed with two children, namely, Linatun Nafisah and Zaimatus Sofia. (Nurul Islam, 2007: 56)

\section{K.H. Educational History Abdurrahman Chudlori}

As the first child, he hoped that he could continue the mandate to be the caregiver for the Islamic boarding school that his father, K.H Chudlori, has established.

The first education that K.H Abdurrahman took was in the Islamic Boarding School under the care of his father. When he was a teenager, his father ordered him to enter the Al Falah Ploso Islamic Boarding School, Kediri, East Java, in 1956 for four years. While at Ploso, he continued and deepened his religious knowledge. After finishing at $\mathrm{Al}$ Falah Ploso Islamic Boarding School, he entered one of the Islamic boarding schools in Mojo in 1960 for one year and studied in Kediri, East Java, in 1962. After he finished his education in Kediri, East Java, he continued his education at Pondok Pesantren Futuhiyyah in Mranggen, Demak, in 1964 for approximately two years. He entered the Pondok 
Pesantren also to deepen his religious knowledge. Every day at the boarding school is still the same as he was at the Al Falah Ploso Islamic Boarding School, Kediri, East Java. He recites and reads books. During his time at the pesantren, he did not do anything other than reciting the Quran. According to his roommate, when he was at the pesantren, he was a diligent and obedient person in worship. Abdurrahman also has an independent personality and does not like to trouble his friends while in the pesantren (Interview on October 31 $1^{\text {st }}, 2018$ at PP Al-Falah Semarang).

After two years at the Mranggen Futufiyyah Islamic boarding school, he returned to his father's boarding school in Tegalrejo, Magelang. At that time, his father, K.H. Chudlori, took over the care of his boarding school to K.H Abdurrahman Chudlori. He was given this authority after his father died in 1977. Since then K.H Abdurrahman has held the right to care for the Asarama Islamic Education (API) Islamic Boarding School (API), Tegalrejo, Magelang.

In the same year, K.H Abdurrahman Chudlori started his career in Politics. Before being active in politics, he was already involved in NU (Interview on December 8 ${ }^{\text {th }}, 2017$ at PP API). K.H Abdurrahman Chudlori was familiar with the world of politics because his father was also active in politics. It was with his desire and encouragement from his father that made K.H Abdurrahman Chudlori enter the world of politics.

\section{K.H Abdurrahman Chudlori's personality}

Being a leader in a large Islamic boarding school is a challenge for K.H Abdurrahman, were always looked good to be an example for students. K.H Abdurrahman is also a community leader and a model for the community, especially the Tegalrejo community.

K.H Abdurrahman Chudlori is known for his independent personality. He did not like to trouble his friends when he studies at the Islamic boarding school (Interview on October 31 ${ }^{\text {st }}, 2018$ at PP Al-Falah Semarang). In the community, K.H Abdurrahman Chudlori is famous for his kind, wise, wise attitude towards the community and his students. He also places great importance on his community, meaning that the condition and welfare of the community is a top priority, whether related to the fields of education, economy, social, and so on. K.H Abdurrahman is a figure admired, respected, respected, and honored by the community. 
JNUS: Journal of Nahdlatul Ulama Studies, Vol. 2, No. 1, Januari 2021: 47-66

He also believes that he is the one who will need the community, not the people who will need him (Interview on July 21 ${ }^{\text {st }}, 2018$ in Tegalrejo Magelang). It can be seen from several things, including: (1) K.H Abdurrahman Chudlori's attention and concern for public education is very significant, both in religious and general education. (2) His attitude and behavior are always respectful and do not discriminate against the general public. (3) K.H Abdurahman Chudlori's high concern for the fate and condition of society, especially those related to economic and social problems (Nurul Islam, 2007: 62). The attitudes shown by K.H Abdurrahman Chudlori can also illustrate that he has great concern for society.

\section{K.H Abdurrahman Chudlori and the World Islamic Boarding School API}

\section{Islamic Education Dormitory (API)}

Many pesantren have been established for a long time, especially in Java. With different styles of pesantren, such as the Salafiyah, the Qur'an, to the modern Pondok. One of them, in Tegalrejo Magelang, there is a boarding school that has been around for a long time. This boarding school uses the Salafiyah model. Salafiyah itself is teaching that still maintains the most traditional methods, namely sorogan and wetonan. The sorogan method is a teaching and learning system where students read the book studied in front of the ustadz or kyai. Whereas wetonan is a method in kyai was reading the book being reviewed while the students listen and interpret or give meaning to the book (https//www.matsansaga.com/2018/11/pondok-pesantrensalaf.htpl?M=1 accessed on February 20th, 2021).

The Salaf Islamic boarding school in Tegalrejo Magelang is called the Islamic Education Dormitory (API). This pesantren is located in Tepo Hamlet, Delimas Village, Tegalrejo District, Magelang Regency, Central Java. This Islamic Education Boarding School was founded on September $15^{\text {th }}$, 1944, by K.H. Chudlori. Still, it was not until 1947 that the name Islamic Education Dormitory was established by K.H Chudlori (Interview on July 21 ${ }^{\text {st }}, 2018$ in Tegalrejo Magelang). Initially, K.H Chudlori only taught eight students, and this was the capital to build the boarding school, supported by his fellow soldiers in his village. With the birth of 
the Islamic Education Boarding School in Tegalrejo, he hopes that his students will develop and teach Islamic syari'at with perseverance and courage. (Nurul Islam, 2007: 48-49)

The background of establishing this Islamic education boarding school was the thoughts and concerns of K.H Chudlori, who saw that there were still many people in the Tegalrejo area who did not understand Islam, and there were still many Abangan people. The purpose of establishing a boarding school for Islamic Education Dormitory is to create a generation that has good morals and can make something useful for the community.

At the beginning of the establishment of this boarding school, the community's response was very apprehensive because there were still many people who followed the Javanese sect. It is not uncommon for them to stop their learning activities at the Islamic boarding school for Islamic Education. In the same year, Dutch missionaries were also still active in spreading Christianity in Magelang. Several sources say that Dutch missionaries burned down this boarding school because they felt that the steps taken by Kyai Chudlori were hindering their missionary process (Interview on July 21 $1^{\text {st }}, 2018$ in Tegalrejo Magelang).

In 1947, the Dutch launched the first military aggression and the second army aggression in 1948, as in other areas, Tegalrejo became a bulwark against the Indonesian guerrillas. Kyai Chudlori permitted more than 70 students to participate in guerrilla warfare. The activities of the pesantren stopped, and the Dutch demolished the building. It was used as a barracks in Pakis (one of the areas in Magelang, near Tegalrejo). K.H Chudlori's house was confiscated to be used as the headquarters of the Dutch military in the area. He and his family were forced to flee, moving to another village (Bambang Pranowo, 2009: 179).

After being established for three years, the community's response to Islamic education boarding schools began to change. This change can be seen from society's attitude, which was initially negative and gradually subsided and disappeared (Nurul Islam, 2007: 50). And over time, this boarding school began to develop, and the increasing number of students studying at the API Islamic boarding school. The development of the Islamic Education Dormitory boarding school is also inseparable from the 
JNUS: Journal of Nahdlatul Ulama Studies, Vol. 2, No. 1, Januari 2021: 47-66

attitude of K.H Chudlori, who is patient and strong in facing the challenges that come.

In 1977 this pesantren experienced its heyday because this year the number of students in Tegalrejo numbered one thousand and five hundred people. In this year, also K.H. Abdurrahman Chudlori, the eldest son of K.H. Chudlori, had just finished his education at Pondok Pesantren Futuhiyah, Mranggen, Demak, Central Java. At that time, K.H Abdurrahman Chudlori immediately returned to Tegalrejo to help teach and manage the API cottage. In addressing the cottage that his father set up, K.H Abdurrahman Chudlori was assisted by his brother K.H Achmad Muhammad, the second son of K.H Chudlori. Besides that, Mbah Dur, the nickname of K.H. Abdurrahman Chudlori, began studying political science at his father's will. 1977 was also a year of mourning for the Tegalrejo family because K.H. Chudlori breathed her last and left a deep wound for her family and students. After the death of K.H. Chudlori, boarding school was continued by his eldest son, namely K.H. Abdurrahman Chudlori.

\section{API Islamic Islamic Boarding School Learning System}

As with Pondok Salafiyah in general, the API Tegalrejo learning system also uses the sorogan and wetonan methods, and the learning is divided into classes. Each student must pass eight classes. The first class is divided into two, namely the Shifir class. This class learns about reading and writing Arabic, Tarikh or History, Sorogan Juz Amma, Fasholatan, and the Ibtidaiyyah class which studies the tartil of Al-Qur'an, Ta'limul Muta'allim, Khottul Jamil, Fiqih Jawan, Jurumiyyah Jawan and Tajwid Jawan. The second class of Jurumiyyah, which studies Jurumiyyah, Safinnatun Najah, Tartil Al-Qur'an, Tadjwid and Aqidatul Awam. Then the third grade is As-saraf, which studies As-saraf, Al-Imrithi, Qoa'idul I'rop, Fathul Qorib. The fourth grade is Alfiyyah, which studied Alfiyyah Ibnu Malik and Minhajud Qowim.

Meanwhile, the fifth class is Fathul Wahab, which includes Fathul Wahab, Jauharul Maknun, and the deepening of Fathul Qorib Ula. AlMahally's sixth-grade studies Al-Mahally, Mantiq, Faroidl, and Fathul Wahab Tsani. The seventh grade of Al-Bukhori includes, Al-Bukhori, Qua'idul Fiqhiyyah, and Bahtsul Masail (Interview on 31 October 2018 at 
Wates Semarang). This learning system has taken place from the management of K.H Chudlori, and it is used during the management of K.H Abdurrahman Chudlori even now.

\section{Modernization of API Tegalrejo Islamic Boarding School}

After K.H Chudlori left, the management of API Tegalrejo Islamic Boarding School was continued by his eldest son, K.H Abdurrahman Chudlori. The late Kyai Chudlori ran the Tegalrejo Islamic Boarding School himself. He was a teacher for the students. He led the residents' weekly recitation, gave spiritual direction, and so on. He has his leadership style, which is also different from the leadership style of his father, K.H Chudlori. Even so, K.H Abdurrahman Chudlori realized the success achieved by his father, so he tried to maintain all the activities his father pioneered and keep the pesantren from changing (Bambang Pranowo, 2009: 180).

When the management of KH Chudlori, API had around 1500 students. At the beginning of Mbah Dur's firmness, API experienced a decrease of up to half of the number of students during the management of KH Chudlori because public trust in K.H. Abdurrahman Chudlori was still lacking. It was considered too young to take care of a large Islamic boarding school. However, with the persistence of K.H Abdurrahman Chudlori in proving to the community, he was able to take care of the boarding school, and it was confirmed after several years he cared for the boarding school around the 2000s. The number of santri finally increased (Interview on October 31 ${ }^{\text {st }}, 2018$ at PP Al-Falah Semarang).

Even though K.H Abdurrahman Chudlori has been entrusted with managing the Islamic Education Dormitory Boarding School, he does not only focus on the Islamic Boarding School. K.H Abdurrahman also carried out his preaching activities in the community. He carried out his da'wah activities in education, economics, social society, and politics.

Da'wah activities in the economic sector are realized through the guidance and development of Baitul Mu'awanah. Bairul Mu'awanah is an institution founded by K.H Abdurrahman Chudlori. This institution is engaged in economics. This institution functions to collect zakat, donations, and shodaqoh from the surrounding community and help the less fortunate. These actions are done by providing business capital 
JNUS: Journal of Nahdlatul Ulama Studies, Vol. 2, No. 1, Januari 2021: 47-66

assistance and providing jobs at the Tegalrejo Magelang Islamic Boarding School (Nurul Islam, 2007: 56-57). Meanwhile, the da'wah activities carried out by K.H Abdurrahman Chudlori in the political field made it happen by joining the PPP, PKB, and PKNU parties.

While K.H. Abdurrahman Chudlori's activities in the field of education, he also had the idea of building a cottage that focused on religious education and paid attention to formal education.

As time went on, K.H Abdurrahman Chudlori had thoughts about formal education in his pesantren. In 2007, API Asri, better known as Syubanul Wathon was established, a boarding school in general, but added formal education such as public schools. He thought about this formal school for a long time, but it was only realized in 2007.

The establishment of Syubanul Wathon was based on the condition of the community, who wanted the boarding school not only to learn about religious education but also general science like schools in general. Therefore Mbah Dur had the thought of establishing a boarding school, and also, in it, there was a formal school. And in 2007, K.H Yusuf Chudlori, who was none other than K.H Abdurrahman Chudlori's younger brother, founded the Syubbanul Wathon Foundation (Interview on December $08^{\text {th }}, 2017$ at PP API).

Since Syubanul Wathon was founded, many people have started entrusting their children to study at Syubanul Wathon, not only from the surrounding community but also outside the city and even outside Java.

\section{K.H Abdurrahman Chudlori's Gait in World Politics Political Trends among Kyai}

On November 03 ${ }^{\text {rd }}, 1945$, an announcement was issued by the Government of the Republic of Indonesia regarding the formation of political parties. After the issuance of the mandate, many parties emerged. Even before the proclamation of August 1945, it had been planned by the Preparatory Committee for Indonesian Independence (PPKI) to form the Indonesian National Party (PNI) as a single party to want an Indonesian state that was sovereign, just, and prosperous based on the sovereignty of the people. The Indonesian National Party only held activities after the issuance of the edict, which became significant members of government officials and civil servants (Jamilatul Na'fiah, 2015: 37). 
After the existence of the Indonesian National Party, in the same year, a Muslim Ummah Congress was also held in Yogyakarta. The Masyumi (Majelis Syuro Muslimin Indonesia) was formed as the only political forum that represented Muslims in Indonesia to uphold the sovereignty of the Republic of Indonesia and carry out their Islamic ideals in State affairs (Jamilatul Na'fiah, 2015: 37), (Masyumi itself is a party that represents Islamic organizations, such as Muhammadiyah, NU and Persis.

NU's participation in politics has begun to appear since the formation of Masyumi, a forum for Islamic organizations. NU's involvement in political issues is based on the understanding that Islam regulates freedom for its people to participate in politics. So theoretically and practically, participation in politics is one of the recommendations allowed by Islam. NU's support for Masyumi made Masyumi the political party with the most prominent followers of its time because NU had many supporters (Tamaddun, 2020: 103).

The birth of the Masyumi Party as the only forum for Islamic political aspirations was able to unite Islamic groups with different views. Even so, it cannot unify the different visions between groups. In 1952 NU decided to leave Masyumi due to several factors, one of which was differences in religious perspectives. According to NU, since the end of 1949, the Masyumi organizational structure has been changed in such a way that it no longer considers the Syuro Council to be an essential forum for kyai because the assembly is no longer a legislative body but only as an advisory board, all problems related to the Masyumi Party if they are to take it. decisions are seen from a political point of view and no longer take religious guidelines (Tamaddun, 2020: 106)

The involvement of the kyai in Indonesian politics was seen after NU left Masyumi due to different views, and not long after leaving Masyumi, NU formed its political party. It was at the party that NU started that the kyai became more active in Indonesian politics (Fairus Kadomi, 2020: 70-71). The development of practical politics in Indonesia brought several kyai who directly or indirectly participated in it since 1955 after implementing a multiparty electoral system.

The role of the Kyai in politics got bigger after NU left Masyumi. Indonesian political history notes that the Nahdlatul Ulama Party, supported by the kyai, became a powerful force and weapon to gain NU 
JNUS: Journal of Nahdlatul Ulama Studies, Vol. 2, No. 1, Januari 2021: 47-66

votes when it became politics. From 1955 to 1971, evidence was that the role of the kyai in politics was able to mobilize the masses so that NU became a fairly large party in Indonesia (Sadi, 2016: 12).

In Islamic society, kyai is one of the elites who have a very respectable position and significantly influences the development of that society. Kyai is one of the strategic elites because of his role as a figure with extensive and deep knowledge of Islamic teachings. It is not surprising that the kyai has a powerful influence on society because these people have put a lot of trust in the kyai, who are also considered their leaders. At this point, the roles of the kyai can be seen, one of which is in the aspects of socio-political life in Indonesia (Miftah Faridl, 2007). : 239)

The involvement of the kyai in practical politics gets pros and cons between groups that legitimize kyai in politics and groups that strongly oppose the kyai being involved in politics. The first group argues that the kyai also has political rights and aspirations like other countries' citizens. In contrast, the second group rebukes them. Based on the assumption that the kyai's involvement in politics brings more losses than gains, which is related to the number of people who think politics is "dirty." It is considered inappropriate for kyai and pesantren to be involved in the "dirty" world of politics. (Sadi, 2016:3)

\section{K.H Abdurrahman Chudlori's Gait in World Politics}

In 1973, after the first general election during the New Order era, the government simplified and merged the functions of political parties into three socio-political forces. These parties were the Indonesian Democratic Party (P.D.I.), the United Development Party (PPP), and the Karya Group.

Soeharto's policy on the fusion of political parties made the yardstick for the formation of PPP. The party, which was formed on January 05th, 1973, which is a combination of Islamic parties, was able to usher in its heyday in the history of Indonesian elections. The establishment of PPP was inseparable from five declarators, namely, chairman of PB Nahdlatul Ulama KH Idham Chalid, chairman of the Indonesian Muslim Party H. Mohammad Syafa'at Mintaredja, general chairman of PSII Anwar Tjokroaminoto, general chairman of PERTI H. 
Rusli Halil, and chairman of the United Development group. in the D.P.R. H. Masykur Faction (Ruchil Farchandyta Aqidah, 2019: 24)

The simplification of political parties is carried out to create stability in the life of the nation and state. Historical experience during the previous administration has provided lessons that the divisions that occurred during the Old Order were due to differences in political ideology and unequal perceptions and understanding of Pancasila as the highest source of law in Indonesia (M.C Ricklefs, 2008: 593)

Among PPP, P.D.I., Golongan Karya Party, K.H Abdurrahman Chudlori chose to fight and be active in the United Development Party (PPP). K.H Abdurrahman Chudlori chose to join the PPP party because he was closest and most compatible with the Islamic struggle of Ahli Sunnah Wal Jama'ah. The party's ideology was also in line with what he wanted. According to K.H Abdurrahman Chudlori, the function of political parties as a means of political communication is that political parties carry out their duties and channel various opinions and aspirations of the community to the government (Interview on July 03 ${ }^{\text {rd }}, 2018$ in Candimulyo Magelang). With K.H Abdurrahman Chudlori getting into the world of politics, he can voice people's opinions.

K.H Abdurrahman Chuldori entered politics initially with the NU Party. At first, he did not formally involve in the leadership of NU, but at that time, he was also the chairperson of the NU syuro council at the Magelang regency level. In 1973 a policy of parties emerged to join. Islamic parties entered to become the United Development Party (PPP), from which K.H. Abdurrahman Chudlori was active in PPP (Interview on October 17 $7^{\text {th }}, 2020$ in Secang Magelang). He also participated in the 1977 elections. At that time, he was only a volunteer for the PPP party. After that, he was active in the governing body.

At the beginning of the formation of the party fusion, the thought of $\mathrm{NU}$, one of the second winners in the 1971 general election, dominated and colored the decisions taken by the PPP, especially when facing government policies that were not following Islamic policies. This thought appeared when some of the PPP leaders were drawn from NU's political elites (Khoiron Minan, 2018: 37).

After the 1999 General Election, the community witnessed one by one, the Islamic political parties experiencing internal conflicts 
JNUS: Journal of Nahdlatul Ulama Studies, Vol. 2, No. 1, Januari 2021: 47-66

(Kamarudin, 2013: 30-31). In the PPP party, the journey as a party fusion was not smooth. The proof, NU left the PPP Party. The breakdown of the relationship between NU and PPP was preceded by PPP decision on the Election Bill discussed at the DPR-RI. John Naro, Chairman of the PPP, approved the Election Bill without NU's approval. Some NU ulama considered NU residents only to vote without being given a role. Then followed by other problems that made NU leaders believe they did not benefit from being a member of the PPP Party (Kamarudin, 2013: 56). Furthermore, during the Reformation Order, NU pioneered the establishment of $\mathrm{PKB}$, and at that time, K.H Abdurrahman Chuldori also moved to the PKB Party.

\section{K.H. Abdurrahman Shifts to PKB}

$\mathrm{PKB}$ was born during the transition of the New Order regime to the reform era. It was during this period that many new parties emerged from the aspirations of NU Citizens. From several parties that were equally born by NU members, namely, PNU, SUNNI Party, PKU, and PKB, only $\mathrm{PKB}$ whose birth is facilitated and declared and fully supported by the Nahdlatul Ulama Executive Board (PBNU). It shows that since the birth of PKB, NU cannot be separated from PKB (Fairus Kadomi, 2020: 70).

K.H Abdurrahman Chudlori's progress in the PKB Party began at the beginning of its formation, namely in 1998. The reason why he joined the PKB party was that this party was formed by NU leaders and also NU members. K.H Abdurrahman Chudlori himself was also an activist and NU figure. He is also one of the figures in charge of the emergence or establishment of the PKB Party in Central Java, especially in the Magelang Region.

K.H Abdurrahman Chudlori's role was huge in the PKB Party. When the party was founded, he had immediately become the Syuro Council' with the previous parties' experience and abilities. The Syuro Council itself is the advisory council for the party. With understanding, pathology, and religious knowledge, he can make the PKB Party still exist (Fairus Kadomi, 2020)

After the 1999 elections, internal conflicts within the party began to emerge, one of which occurred in the PKB party. The internal conflict experienced by the PKB party gave birth to a new political party, namely 
PKNU. The PKB conflict can be divided into three periods. The first period was in 2001-2002. The second was between 2004-2007. The parties involved were the Syuro Council Abdurrahman Wahid-Chairman of the Tanfidz Council Muhaimin Iskandar with the PKB congress II and Alwi Shihab- Saifullah Yusuf, who made a counter congress in Surabaya. The third period, the period between 2008-2011, gave birth to the Extraordinary Congress of the Abdurrahman Wahid camp with the Ancol Extraordinary Congress of Muhaimin Iskandar (Kamarudin, 2013: 32).

The PKB's second period of internal conflict was heavier than when there was a clash between Abdurrahman Wahid's camp and Matori Abdul Djalil's camp in the 2001-2002 period. In this second period, there were conflicts, including the involvement of kyai khos (main kyai), who joined in the langitan forum that supports Dr. H. Alwi Shihab and Syaifullah Yusuf. Secondly, the conflict involving East Java and Central Java, in these two provinces, the prominent and influential Islamic boarding schools managed by kyai khos, such as the Langitan Islamic Boarding School and the Lirboyo Islamic Boarding School, contributed $80 \%$ of the total national votes obtained by PKB in the 1999 elections. And 2004. Third, namely, gave birth to a new party called the National Awakening Party (PKNU). And finally, although not directly involved with PKB's internal conflicts, NU's attitude shows that PKB is now not the only political party that accommodates and fights for the interests of the nahdliyin. (Kamarudin, 2013: 32-33)

\section{K.H Abdurrahman Chudlori in the PKNU Party}

The establishment of the PKNU Party was inseparable from a management conflict within the PKB Party. The management conflict within the PKB stems from the dismissal of the General Chairman of the Tanfidz DPP PKB Council, Dr. H. Alwi Shihab. The election of Dr. Alwi Shihab as the General Chair of the Tanfidz Council was carried out in the highest party deliberation forum called the Muktamar. It was stipulated in the PKB congress decisions. However, when Alwi Shihab was dismissed, it was only through the Plenary Meeting of the PKB Central Executive Board.

Efforts have been made to resolve the conflict through deliberation. The kyai who joined the Kyai Langitan forum have told the 
JNUS: Journal of Nahdlatul Ulama Studies, Vol. 2, No. 1, Januari 2021: 47-66

PKB DPP to return Alwi Shihab as General Chair of the PKB DPP Tanfidz Council to be accountable for his performance before the congress. But the request did not get a positive response, so Alwi Shihab took legal steps through the court process. After going through a long process, Alwi Shihab won the lawsuit. However, the losing party interprets the Supreme Court's decision (M.A.) as a decision that does not need to be obeyed because the decision does not explicitly concern which management is legal (Amrul Faiz, 2009: 30-31).

With the PKB conflict, which subsequently took place PKB congress II in Surabaya, the congress made the ulama who joined the 17 teams (Amrul Faiz, 2009: 43), including K.H. Abdurrahman Chudlori, gave birth to a new party, namely PKNU, which was born on November 21st. 2006 took place at Pondok Langitan, Widang Tuban, East Java.

The goal of the PKNU Party is to fight for the upholding of Islam Ahlusunnah Wal Jama'ah in the life of the nation and state in the Republic of Indonesia based on Pancasila U.U.D. 1954. The management of this party is a continuation of the Ulama of $\mathrm{PKB}$, which is perfected in following the internal provisions of the party. There will be changes or changes in the new management in the congress concerning the main criteria that must be cadres who truly understand Ahlusunnah Wal Jama'ah (Amrul Faiz, 2009: 41). PKNU puts forward politics with a new color that has failed to do so by existing political parties. This new political color departs from a religious vision through the guidance of the scholars. This party avoids politics that culminates in power (Amrul Faiz, 2009: 47).

PKNU believes that to realize a just and prosperous people's life, it must commit to the political struggle of all political forces in Indonesia. Therefore, PKNU does not shut down from cooperating with parties with the same vision, mission, and goals.

K.H Abdurrahman Chudlori, in this party, is the chairperson of the Shura council, the party's supreme council that makes and sets general guidelines for party policies to serve as the primary reference for implementing party policies. But that position did not last long because, in 2010, he was getting sick, and on January 24th, 2011, he was called the One and Only. Not long after the death of K.H Abdurrahman Chudlori, the PKNU Party in the 2014 election did not pass verification. Since then, 
PKNU has also been no longer active in Indonesian politics (Interview on July 03 $3^{\text {rd }}, 2018$ in Candimulyo Magelang).

\section{CONCLUSION}

Based on the discussion that has been described in previous chapters, the following conclusions can be drawn:

1. K.H Abdurrahman Chudlori is a religious figure who was born on December 31, 1943 in Tegalrejo, Magelang, Central Java. He was born to K.H Chudlori, and his mother was named Mrs. Khunah. K.H Abdurrahman Chudlori is the first of three children. K.H Abdurrahman Chudlori was born into a priyai family. His father was a great scholar and founder of the API Islamic Boarding School located in Tegalrejo, Magelang. His childhood was spent seeking knowledge under the care of his father after he was a teenager in the Islamic boarding school. After completing his education, he was assigned by his father to take care of the cottage with his brother. K.H Abdurrahman Chudlori is a figure who is respected, admired wise, wise, protective, and charismatic.

2. K.H. Abdurrahman Chudlori's journey in raising his pesantren was not easy because of the change in leadership, which made the community doubt the ability of K.H. Abdurrahman Chudlori at that time. At the beginning of his stewardship, the number of students had decreased. Still, with the persistence he had after several years under K.H. Abdurrahman Chudlori, the pesantren reached glory with the increasing number of students who learn even more from the nurturing of their fathers. Not only caring for and developing the boarding school that his father founded, but he also had the idea of making a boarding school with a formal school, but his younger brother K.H Yusuf Chudlori realized this desire.

3. K.H Abdurrahman Chudlori is also active in politics. Initially, he was involved in NU After the New Order and the government, politics simplified and merged parties into only three parties, one of which was the PPP which was a joint party of various Islamic parties. Finally, K.H Abdurrahman 
JNUS: Journal of Nahdlatul Ulama Studies, Vol. 2, No. 1, Januari 2021: 47-66

was also active in PPP because of NU was also part of the PPP division. After NU left PPP and NU figures formed a new party, namely the PKB Party. K.H Abdurrahman Chudlori also chose to move and become part of the PKB party. He also briefly occupied the Syuro Council seat in the party. After the 1999 election, an internal conflict occurred within the PKB Party, which finally gave birth to a new party, namely PKNU. Not only active in his new party, but K.H Abdurrahman Chudlori is also one of the 17 founders of the PKNU Party. His position in PKNU was the chairman of the Syuro Council.

\section{REFERENCES}

Ahmadi. October 31 ${ }^{\text {st }}$ 2018. An interview about K.H Abdurrahman Chudlori as the Leader of API Tegalrejo Islamic Boarding School. in Wates Village, Semarang.

Amri, Saifil. November 2017, An interview about K.H Abdurrahman Chudlori as caretaker of the Islamic Boarding School at API Islamic Boarding School, Tegalrejo, Magelang.

Arif, Nasrul. December $8^{\text {th }}$ 2017, An interview about the biography of K.H Abdurrahman Chudlori, at API Islamic Boarding School, Tegalrejo, Magelang.

Arifin, Zaenal. June $3^{\text {rd }}$ 2018, An interview about K.H Abdurrahman Chudlori's role in the world of politics in Bojong, Giyanti, Candimulyo, Magelang.

Arifin, Zaenal. October $17^{\text {th }} 2020$, An interview about the role of K.H Abdurrahman Chudlori in the world of politics in Pucang, Secang, Magelang.

Aqidah, Ruchil Farchandyta. 2019. Partai Persatuan Pembangunan (PPP) Pada Masa Orde Baru (Studi Historis Pemilu 1977 di Indonesia). Thesis. UIN Sunan Ampel Surabaya.

Bachrudin. July 21 $1^{\text {st }}$ 2018. An interview about K.H Abdurrahman Chudlori as the Leader of API Tegalrejo Islamic Boarding School. In Burikan Village, Dlimas, Tegalrejo, Magelang.

Faiz, Amrul. 2009. Konsep Ablussunnah Wal Jamaah (Aswaja) Dalam Politik Partai Kebangkitan Nasional Ulama (PKNU): Implikasi Politik. 
Islam Ablussunnab Wal Jamaah Dalam Konteks Negara Bangsa,

NKRI. Thesis. UIN Sunan Ampel Surabaya.

Faridl, Miftah. 2007. Peran Sosial Politike Kyai di Indonesia, Jurnal Sosiotekhnologi, Ed. 11 August.

Gottschalk, Louis. 1975. Mengerti Sejarah, translated Nugroho

Notosusanto. Jakarta: Yayasan Penerbit Universitas

Indonesia

https//www.matsansaga.com/2018/11/pondok-pesantren-

salaf.htpl?m=1 diakses pada 20 Februari 2021.

Islam, Nurul. 2007. Kepemimpinan K.H. Abdurrabman Khudlori Dalam Upaya

Pengembangan Pondok Pesantren Asrama Perguruan Islam

Tegalrejo Magelang Sebagai Lembaga Dakwah. Thesis.

Semarang: IAIN Walisongo.

Kadomi, Muhammad Fairus. 2020. Peran K.H. Mabfudz. Ridwan Dalam

Partai Kebangkitan Bangsa 1998-2008. Thesis. IAIN Salatiga.

Kamarudin. 2013. Konflik Internal Partai Politik: Studi Kasus Partai

Kebangkitan Bangsa, Jurnal Penelitian Politik, V 10 No 1 June.

Minan, Ahmad Khoiron. 2018. Partai Persatuan Pembangunan Pasca

Kembalinya NU ke Khittah 1926 tahun 1984-1994. Thesis.

UIN Sunan Ampel Surabaya.

Nafi'ah, Jamilatun. 2015. Biografi H.Marijoen Hardjosoemarto Marijun

Haryosumarto) 1916-2004. Thesis. UIN Sunan Ampel

Surabaya.

Pranowo, Bambang. 2009. Memahami Islam Jawa. Jakarta: Pustaka Alvabet.

Ricklefs. M.C. 2008. Sejarah Indonesia Modern 1200-2008. Jakarta: Serambi.

Ro'yi, Syamsul. October 30 ${ }^{\text {th }}$ 2018. An interview about the life of K.H

Abdurrahman Chudlori during his life at Pondok. at $\mathrm{Al}$

Riyadloh Kesongo Islamic Boarding School, Tuntang.

Sadi. 2016. Kyai dan Politik: Mengintip Motif Kyai NU (Nabdlatul Ulama)

dalam Pemilu 2009 di Glenmore Kabupaten Banywwangi. Jurnal

Ilmiah Kependidikan. Vol. X No 1. September.

Tamaddun. 2020. Dinamika Partai Nabdlatul Ulama pada Pemilihan Umum

1955 di Jawa Barat. Jurnal Sejarah Kebudayaan Islam. Vol

8. Juli. 
JNUS: Journal of Nahdlatul Ulama Studies, Vol. 2, No. 1, Januari 2021: 47-66

Yasin. October $31^{\text {st }}$ 2018. K.H Abdurrahman Chudlori's life while living in Pondok. at Al Falah Islamic Boarding School, Bergas, Semarang. 